Ann. Biol. anim. Bioch. Biophys., 1978, 18 (4), 917-921.

\title{
The annual reproduction cycle in adult carp in Poland : ovarian state and serum gonadotropin level
}

\author{
par K. BIENIARZ, P. EPLER, B. BRETON *, Luong Noc THUY \\ Institute of Applied Zoology, Academy of Agriculture, 30-059 Krakow, Poland \\ * Laboratoire de Physiologie des Poissons, I.N.R.A. \\ 78350 Jouy en Josas, France.
}

\begin{abstract}
Summary. In environmental conditions in Poland, new vitellogenesis began in carp just after the spawning seasc $n$. This phase was correlated with the maintenance of a high serum, gonadotropin level, which decreased and remained low when the temperature was also low ; oogenesis remained blocked at the stage attained before the drop in temperature and gonadotropin level. The rise of temperature in May increased GTH and ovarian responsiveness to hypophysation treatment. Although pituitary function seemed normal in some fish, there was no spawning even after hypophysation treatment. Resorbing oocytes were present during the whole year, and a minimum rate of GTH secretion would be necessary to prevent massive resorption. Animals were ready for a new reproduction cycle right after spawning ; this could not be achieved with the environmental conditions in Poland, namely the temperature. Existence of a limit temperature is discussed.
\end{abstract}

\section{Introduction.}

Most female carp in Poland reach sexual maturity in the fifth year of life, but some may attain it in the fourth year. Spawning occurs once a year in late May when the temperature reaches $18^{\circ} \mathrm{C}$. The female ovaries regenerate a few weeks after spawning and are ready for the next spawning (Bieniarz et al., 1977). All stages of oogenesis are present in the ovary during spawning (Bieniarz et al., 1977 ; Brzuska, 1977). Few data are available in the literature on gonadotropin regulation of vitellogenesis and the final stages of oogenesis, but the increase of pituitary responsiveness to hypothalamic hormones at the final maturation stage of the ovary has been correlated with temperature by Weil ef al. (1975).

In the present report, we investigated the evolution of ovarian development in correlation with serum GTH concentration.

\section{Material and methods.}

The experiment was carried out between July 1975 and July 1976 on 5-year old female carp weighing 3 to $4 \mathrm{~kg}$ and kept in a conventional pond under normal rearing conditions. At the end of the experiment the animals were divided into 4 groups 
according to the time and the number of animals spawning :1. Spawning in June 1975 and June 1976 (5 animals) ; 2. Spawning in June 1975 but not in 1976 (10 animals); 3. Spawning in June 1976 but not in 1975 (11 animals) ; 4. No spawning in either 1975 or 1976.

Group 2 females had spawned naturally in 1975. In the other groups all spawnings were induced by hypophysation ( $4 \mathrm{mg}$ pituitary powder per $\mathrm{kg}$ body weight). Blood was sampled monthly from the caudal vein at $11 \mathrm{a}$. $\mathrm{m}$. After coagulation and centrifugation sera were kept frozen af $-20^{\circ} \mathrm{C}$ until gonadotropin (GTH) determination by radioimmunoassay according to Breton ef al. (1971).

Ovarian samples were taken in vivo by means of intraabdominal puncture using the technique described earlier (Bieniarz and Epler, 1976). Young oocytes $(<0.9 \mathrm{~mm}$ diameter) were estimated to permanently represent 50 p. 100 of the total number of oocytes. Large oocytes $(0.9$ to $1.3 \mathrm{~mm})$ with completed vitellogenesis were classified as follows : Stage 1 : nucleus in the center of the oocyte ; Stage 2 : nucleus shifted to oocyte periphery; Stage 3 : resorbing oocytes characterized by a disorganized inner structure.

The results were statistically analyzed by the t-test.

\section{Results.}

No statistical differences were found between the serum gonadotropin levels in the first 3 groups (fig. 1). High GTH levels were observed from July to September, which then decreased and remained low up to May. Between May 19 and June 7 , serum GTH secretion rose from $0.83 \mathrm{ng} / \mathrm{ml}$ to about $2 \mathrm{ng} / \mathrm{ml}$. The serum GTH concentration was lower one month after than in the days preceding spawning $(0.24 \mathrm{ng} / \mathrm{ml}$ against $1.44 \mathrm{ng} / \mathrm{ml}$ ). In group 4 where no spawning had occurred, the same type of secretion curve was noted, but a significant final increase of serum GTH was observed

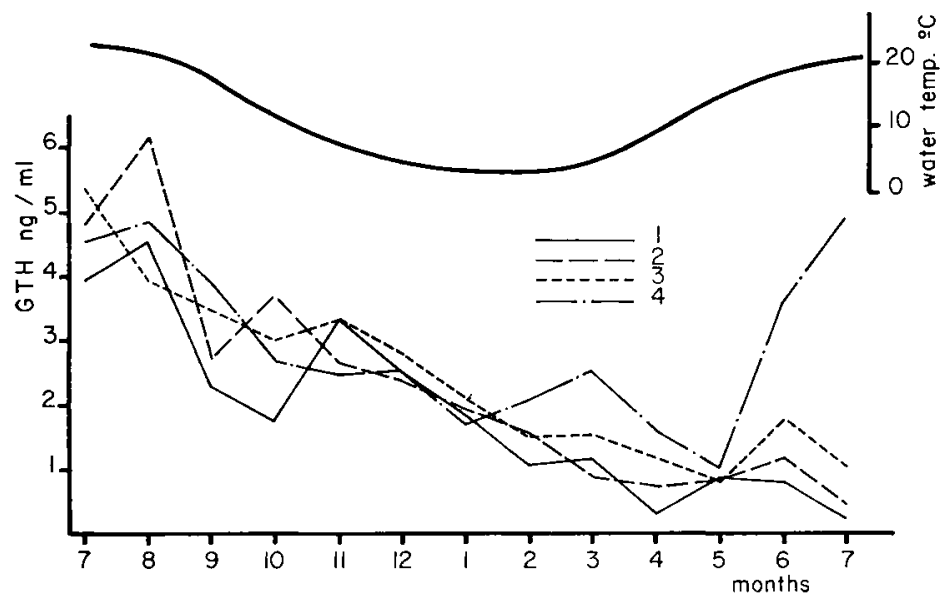

FIG. 1. - Top : annual change in water temperature. Bottom : changes in blood gonadotropin level of females carp during the reproductive cycle. 1 : group 1 females which spawned in 1975 and 1976 ; 2 : group 2 females which spawned only in $1975 ; 3$ : group 3 females which spawned only in 1976 ; 4 : group 4 females which did not spawn. 
in comparison with other groups $(3.54 \mathrm{ng} / \mathrm{ml})$. The $\mathrm{GTH}$ level continued to increase up to $4.92 \mathrm{ng} / \mathrm{ml}$ after the presumed spawning period.

In the first 3 groups, there were no statistical differences in the percentages of the different oocyte stages during the dates cited above ; figure 2 shows the curve of evolution of these parameters. Stage 1 represents about 50 p. 100 of the oocytes from July to October. From this period their decrease in number correlated with a rise in the percentage of type 2 oocytes. The number of stage 2 oocytes remained high until the spawning season, except for a small decrease occurring in May at the same time as a peak of resorbing oocytes. After spawning, the percentage of stage 2 oocytes declined to 15 p. 100 , corresponding to the generation of new oocytes in stage 1. In these 3 groups resorbing oocytes always represent 20 to 30 p. 100 of the ovarian germ cells.

Groups 4 differs from the others only by the fact that resorbing oocytes continued to increase after the normal spawning season.

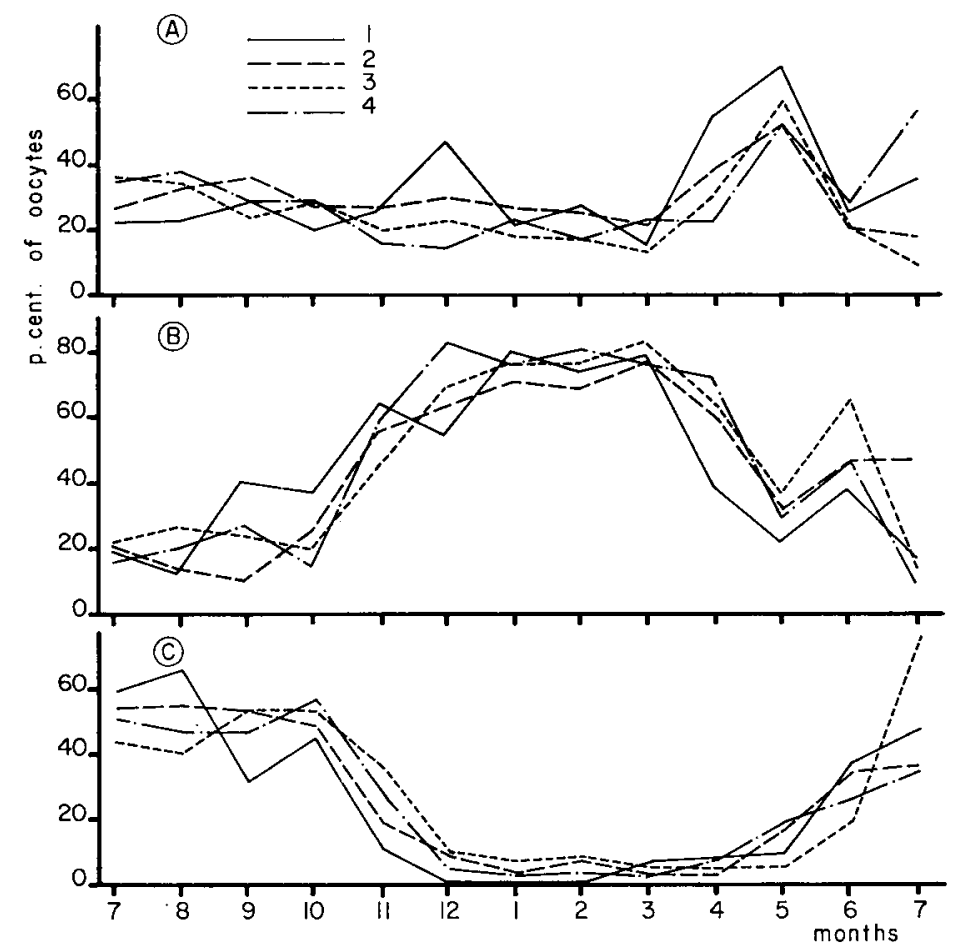

FIG. 2. - Changes in the percentage of resorbing oocytes (A), oocytes with the nucleus in position « $2 »(B)$, or oocytes with the nucleus in position «1»(C) during an annual reproductive cycle in female carp. $1,2,3,4$ : experimental groups, see figure 1 .

\section{Discussion.}

GTH levels remained high in all groups from July to September and did not decrease after the spawning season. In other studies, Bieniarz and Epler (1976) have demonstrated a new vitellogenesis occurring in carp within 2 months after spawning. 
The present results are in agreement with those findings. The high serum GTH levels observed from July to September could be correlated with vitellogenesis stimulation, as already demonstrated in trout and tench (Breton et al., 1975). Afterwards, GTH levels remain low until the onset of the spawning season; they begin to rise slowly in May and June in the first 3 groups when the temperature reaches about $14{ }^{\circ} \mathrm{C}$. Therefore, GTH levels are higher before spawning than after, indicating that spawning may be under gonadotropin control. A peak of serum GTH secretion is not observed during this period, possibly because it would have been necessary to take samples more than once a month to detect such a rise. An alternative explanation may be that in the present experiment females usually did not spawn spontaneously and ovulation had to be induced by hypophysation. In this hypothesis, no blood GTH surge is expected and only an elevation of the GTH base line level is obtained.

It must also be emphasized that an increase of resorbing oocytes occurs in April and May when the serum GTH level reaches minimum values. Thus, in carp it seems that a limit value of GTH secretion is necessary to prevent massive oocyte resorption. It is interesting to note that the resorption peak appears at the end of the coldest period and at the spring rise in temperature.

There is no spawning in group 4, even after hypophysation although GTH level is higher than in the other groups. It may be hypothesized that in these animals gonadotropin secretion occurs normally, but there is lack of ovarian GTH responsiveness leading to resorption.

As early as October, the number of oocytes in stage 2 increases and reaches a maximum in December. Thus, immediately after spawning the animals are ready for a new reproduction cycle which cannot be achieved in the natural environmental conditions in Pcland, mainly due to the temperature.

Temperature seems to the most important factor in the carp since maintenance at high temperature $\left(23^{\circ} \mathrm{C}\right.$ ) accelerates ovarian recrudescence and spawning (Gupta, 1975). It is difficult to determine the limit temperature under which reproduction cannot take place in carp, but it may around $14^{\circ} \mathrm{C}$. For example, Pandey and Hoar (1972) were able to induce vitellogenesis and spawning by clomiphene in goldfish reared at $14^{\circ} \mathrm{C}$. It is also possible to induce spawning in carp using a sequential treatment (pituitary extract and $17 \alpha$-hydroxy-203-dihydroprogesterone) at $14^{\circ} \mathrm{C}$ (Jalabert ef al., 1977), but this cannot be done at $10^{\circ} \mathrm{C}$ (Breton ef al., unpublished data). This temperature also corresponds either to the decrease of GTH secretion in September or to the spring rise of GTH in this experiment.

\section{Conclusion.}

In environmental conditions in Poland, the new oogenetic carp cycle (oocyte maturation and ovulation) starts right after spawning and does not end in the same year, probably because of the drop in ambiant temperature. During the coldest period stage 2 oocytes (with peripheric nucleus) remain in a quiescent stage until a rise in temperature the following spring leads to a rise of gonadotropin secretion and oocyte maturation. 
Résumé. Chez la Carpe, dans les conditions polonaises d'élevage, une nouvelle vitellogenèse démarre aussitôt après la fraie. Cette phase est corrélée avec le maintien d'un haut niveau de sécrétion de gonadotropine. Le niveau décroît et reste faible lorsque la température est elle-même basse, la vitellogenèse restant bloquée au stade atteint avant la décroissance de la température, ef du niveau sérique de GTH. L'élévation de la température au printemps conduit à une augmentation de la GTH sérique et à l'apparition de la réceptivité ovarienne au traitement d'hypophysation. Dans certains cas, bien que le fonctionnement gonadotrope hypophysaire apparaisse normal, l'ovaire n'est pas réceptif au traitement d'hypophysation. Des ovocytes en résorption sont présents tout le long de l'année ; un seuil minimum de GTH pourrait être nécessaire pour prévenir une résorption massive. En conclusion, juste après la fraie les animaux sont prêts à engager un nouveau cycle de reproduction, qui ne peut s'achever en raison de conditions d'environnement défavorables, principalement la température. L'existence d'une température limite est discutée.

\section{References}

BIENIARZ K., EPLER P., 1976. Preliminary results of the in vivo studies on ovarian resorption in carp Cyprinus carpio L. J. Fish Biol., 8, 449-451.

BIENIARZ K., EPLER P., POPEK W., 1977. Histological changes in the ovaries of mature female carp in summer time. Invest. Pesq., 41, 95-102.

BRETON B., KANN G., BURZAWA-GERARD E., BILLARD R., 1971. Dosage radioimmunologique d'une hormone gonadotrope de carpe Cyprinus carpio L. C. R. Acad. Sci. Paris, série D, 272, 1515-1517.

BRETON B., JALABERT B., FOSTIER A., BILLARD R., 1975. Etude sur le cycle reproducteur de la truite Arc-en-ciel et de la tanche. J. Physiol., 70, 561-564.

BRZUSKA E., 1977. In vivo studies on oocyfe maturation in carp Cyprinus carpio L. Doctor's Thesis. Acad. Agric. Cracov, Poland.

GUPTA S., 1975. The development of carp gonads in warm water aquaria. J. Fish. Biol., 7, 775-782.

JALABERT B., BRETON B., BRZUSKA E., FOSTIER A., WIENIAWSKI J., 1977. A new tool for induced spawning ; the use of $17 \alpha$ hydroxy-20 $\beta$ dihydroprogesterone to spawn carp at low temperature. Aquaculture, 10, 353-364.

PANDEY S., HOAR W. S., 1972. Induction of ovulation in goldfish by clomiphene citrate. Can. J. Zool., 50, 1679-1680.

WEIL C., BRETON B., REINAUD P., 1975. Etude de la réponse hypophysaire à l'administration de Gn-RH exogène au cours du cycle reproducteur annuel chez la carpe Cyprinus carpio L., C. R. Acad. Sci. Paris, série D, 280, 2469-2472. 